\title{
Characterization of weathering profile in granites and volcanosedimentary rocks in West Africa under humid tropical climate conditions. Case of the Dimbokro Catchment (Ivory Coast)
}

\author{
M Koita $^{1,2, *}$, H Jourde ${ }^{1}$, K J P Koffir ${ }^{3}$, K S Da Silveira ${ }^{1}$ and A Biaou ${ }^{1}$ \\ ${ }^{1}$ Water and Climate Research Center, International Institute for Water \\ and Environmental Engineering (2iE), 01 BP 594 Ouagadougou, Burkina Faso. \\ ${ }^{2}$ Laboratoire HydroSciences Montpellier, Université de Montpellier 2, Place E. Bataillon, \\ F-34395 Montpellier Cedex 5, France. \\ ${ }^{3}$ Laboratoire Géosciences et Environnement, Université d'Abobo-Adjamé, \\ BP 801 Abidjan 02 Côte d'Ivoire. \\ ${ }^{*}$ Corresponding author.e-mail: kmahamoudk@yahoo.fr
}

\begin{abstract}
In granitic rocks, various models of weathering profile have been proposed, but never for the hard rocks of West Africa. Besides, in the literature there is no description of the weathering profile in volcanosedimentrary rocks. Therefore, we propose three models describing the weathering profiles in granites, metasediments, and volcanic rocks for hard rock formations located in West Africa. For each of these models proposed for granitic and volcanosedimentary rocks of the Dimbokro catchment, vertical layered weathering profiles are described, according to the various weathering and erosion cycles (specific to West Africa) that the geological formations of the Dimbokro catchment experienced from the Eocene to the recent Quaternary period. The characterization of weathering profiles is based on: i) bedrocks and weathering profile observations at outcrop, and ii) interpretation and synthesis of geophysical data and lithologs from different boreholes. For each of the geological formations (granites, metasediments, and volcanic rocks), their related weathering profile model depicted from top to bottom comprises four separate layers: alloterite, isalterite, fissured layer, and fractured fresh basement. These weathering profiles are systematically covered by a soil layer. Though granites, metasediments and volcanic rocks of the Dimbokro catchment experience the same weathering and erosion cycles during the palaeoclimatic fluctuations from Eocene to recent Quaternary period, they exhibit differences in thickness. In granites, the weathering profile is relatively thin due to the absence of iron crust which protects weathering products against dismantling. In metasediments and volcanic rocks iron crusts develop better than in granites; in these rocks the alterite are more resistant to dismantling.
\end{abstract}

\section{Introduction}

Understanding the dynamics of fractured aquifers in hard rocks and the physics of the flow in the composite layers of the aquifers requires an accurate knowledge of both the geometry and the structure of the weathering profile. The lithological sequences above the crystalline basement can

Keywords. Weathering profile; conceptual model; granites; metasediments; volcanic rocks; Dimbokro catchment; Ivory Coast; West Africa. 
be distinguished by the physical, chemical, mineralogical, geodynamical, and palaeomorphological features (Geirnaert et al. 1984; Wright 1992; Freyssinet and Farah 2000; Taylor and Howard 2000; Dewandel et al. 2006).

Most of the proposed weathering profile models concern granitic rocks. Few investigations, e.g., Peltre (1977) addressed volcanosedimentary formations. Indeed, in volcanosedimentary formations there are significant lateral as well as vertical variations, the original rock type greatly influences the rate of weathering (Nahon 1986).

Lack of consistent, reliable and typical conceptual weathering model of these formations does not allow the estimation of the hydrodynamic properties of the distinct zones of the aquifer and especially the change in their properties along a vertical profile.

This study aims to analyse and describe the typical weathering profiles identified in granites, and also in metasediments and volcanic formations of the Dimbokro catchment (Ivory Coast). It proposes a conceptual model of the vertical structure for each rock type while considering the various weathering and erosion cycles that the geological formations experienced. Finally, a comparative study of the weathering profile geometry is carried out, which allows highlighting of the similarities and differences.

\section{Geological context of the Dimbokro catchment}

\subsection{Geological set-up}

Dimbokro catchment $\left(6300 \mathrm{~km}^{2}\right)$ is part of the River Nzi catchment located in the central eastern part of the Ivory Coast (figure 1), but its geology is poorly known in detail. The geological formations of Dimbokro catchment are divided into two major groups which experienced different tectonometamorphic changes (Yao et al. 1990, 1995): (i) the rocks of the volcanosedimentary complex and (ii) the biotite granites.

Synthesis of the geological history has been done by Tagini (1971), Peltre (1977), and Yao et al. $(1990,1995)$. The granitic domain set-up at 'Liberian' tectono-volcanism (2900 to 2400 million years ago (mya)) and rejuvenated by later 'Eburnean' (about 2200 mya) and 'Birimian' (2000 to 1880 mya) tectono-volcanic phases which constitutes the final phase of the geological set-up. The volcanosedimentary rock set-up which succeeds one of the granitic domain can be summarized in two main steps:

i) Initial step, in the Lower Proterozoic, the reactivation of deep faults by an 'Eburnean' tectono-volcanic phase (about 2200 mya) opened up the long and narrow subsidence in the Liberian platform (2900-2400 mya). During this period, interstratifications of lava and associated sediments flowed out through marginal faults towards an open sea which affected by metamorphism during later paroxysm formed the association of 'green rock' (dominated by metabasalt) and schistose quartzite of the volcanosedimentary complex;

ii) Main deposit step, the 'Birimian' tectonovolcanic phase (2000-1880 mya) generated thick detrital accumulations deposited above volcanosedimentary rocks. The detrital accumulations are classified into three groups from the bottom to the top: conglomerates above which deposit in concordance fine formation where alternate schist and greywacke sometimes; and greywacke (detrtital rock rich in clay and feldspar) at the top. This accumulation phase supposes the existence of a high relief and strong erosion due to intense tectonic movements. Then the detrital accumulation coming from erosion processes was folded and affected by metamorphism during this tectonic paroxysm.

The volcanosedimentary complex and the rocks of detrital accumulation are generally separated by intrabirimian discordance called 'abronian'. The metamorphism affected the rock of detrital accumulation weakly. These formations show a clayey tendency with grey or green colour passing to yellow-green depending on the degree of rock weathering (Maillary 1965).

Like most of the geological formations of West Africa (from Senegal to Nigeria), granites and volcano-sedimentary complex formations experienced cycles of weathering and erosion resulting from palaeoclimatic fluctuations from the Eocene to the recent Quaternary period (Michel 1969). The evidences of these cycles of weathering and erosion are identified through numerous geomorphological units in the Dimbokro catchment: iron crust levelling surfaces.

\subsection{Main phases of the catchment evolution from Eocene to Quaternary}

\subsubsection{Geomorphological considerations}

The geomorphologic evolution of Dimbokro catchment is described by many authors (Bonvallot and Boulangé 1970; Avenard et al. 1971; Michel 1974; Grandin 1976; Peltre 1977). This description focuses on different levels of iron crusts in the basin, which are the evidence of the existence of palaeosurfaces (Grandin 1976). According 


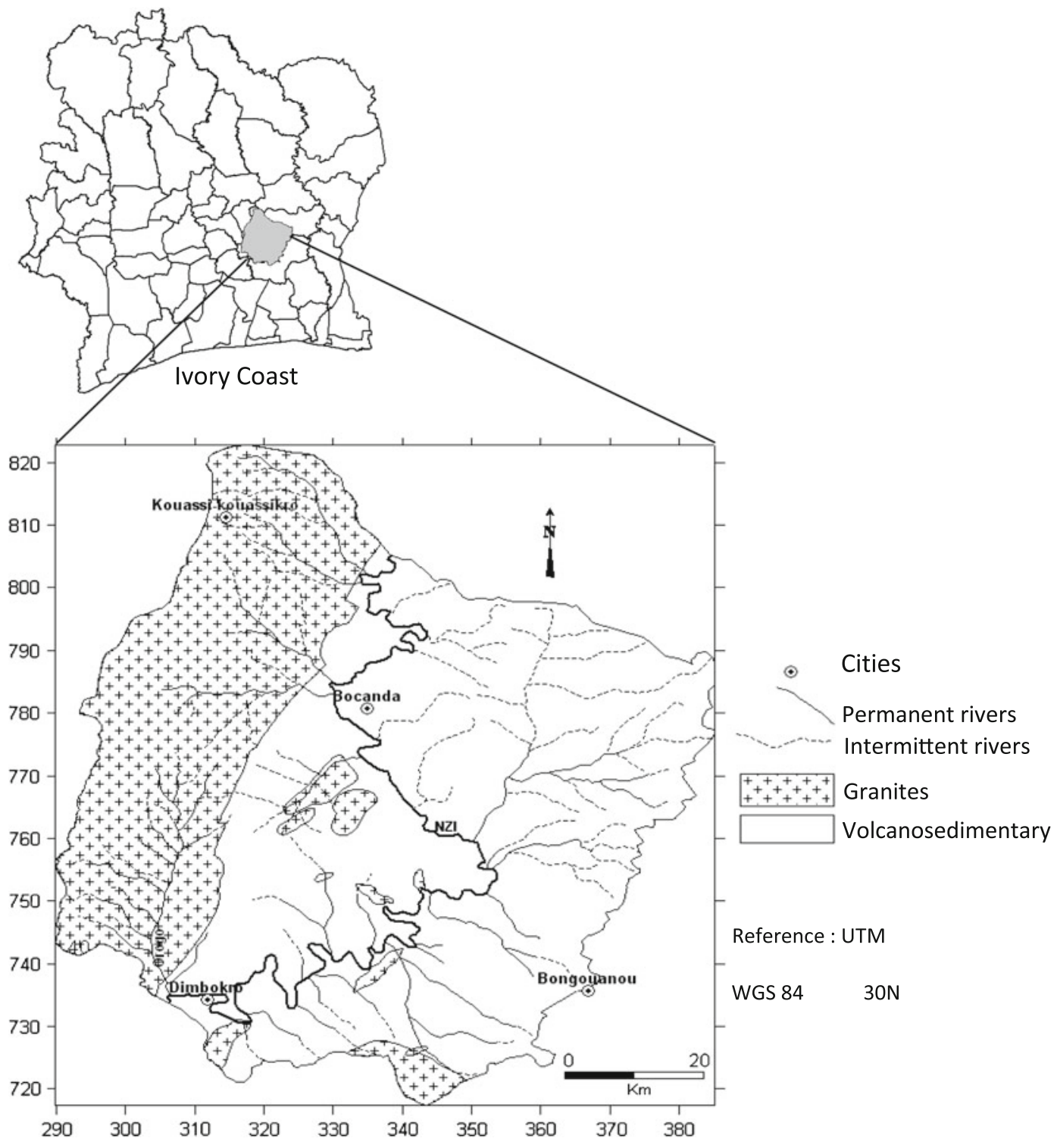

Figure 1. Geology of Dimbokro catchment.

to Blot (1980), the iron crust does not create a specific relief model but maintain the landforms that favour its immobilization. The alterites associated with different iron crust levels are considered contemporary with the iron crust or inherited; in the latter case the new surface is embedded in an early weathering mantle. Generally, the iron that forms the crust comes from early accumulations, and most of the time from early iron crust in high positions, exposed to erosion processes. This 'cascade' distribution of iron involves a succession of episodes of iron mobilization and precipitation in the oxidized form (Michel 1974).

Grandin and Delvigne (1969) and Bonvallot and Boulangé (1970) distinguish five iron crust levels in the catchment and explain their setup by morphoclimatic fluctuations experienced by the Dimbokro-Bongouanou region in general and the Dimbokro catchment in particular during their evolution: bauxite surface, intermediate landforms, high glacis, medium glacis (or high terrace), and low glacis (or alluvial zone). These levels are observed on the Nzi-Bongouanou cross-section (figure 2).

The chronology proposed by Michel (1974) states that the different levels of iron crust in Dimbokro catchment are dated from Eocene to Quaternary. By comparison with iron crust levels in West Africa and more precisely in Senegal and Gambia, Michel (1974) admits that the bauxite surface of the catchment is the equivalent of the 'African surface' and belongs to the Eocene period.

According to Avenard et al. (1971), the intermediate landforms, evidences of an early 'very high glacis', are formed at the end of the Tertiary period (Mio-Pliocene). 


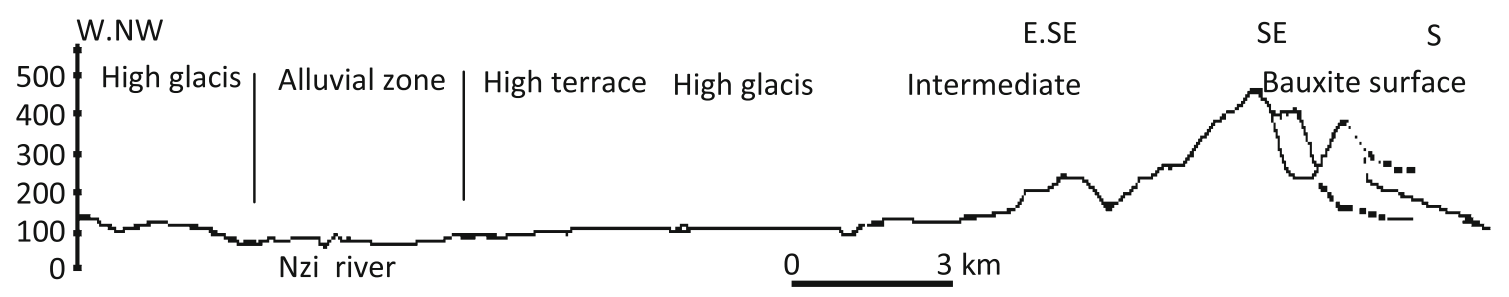

Figure 2. Cross section of Nzi-Bongouanou (after Bonvallot and Boulangé 1970).

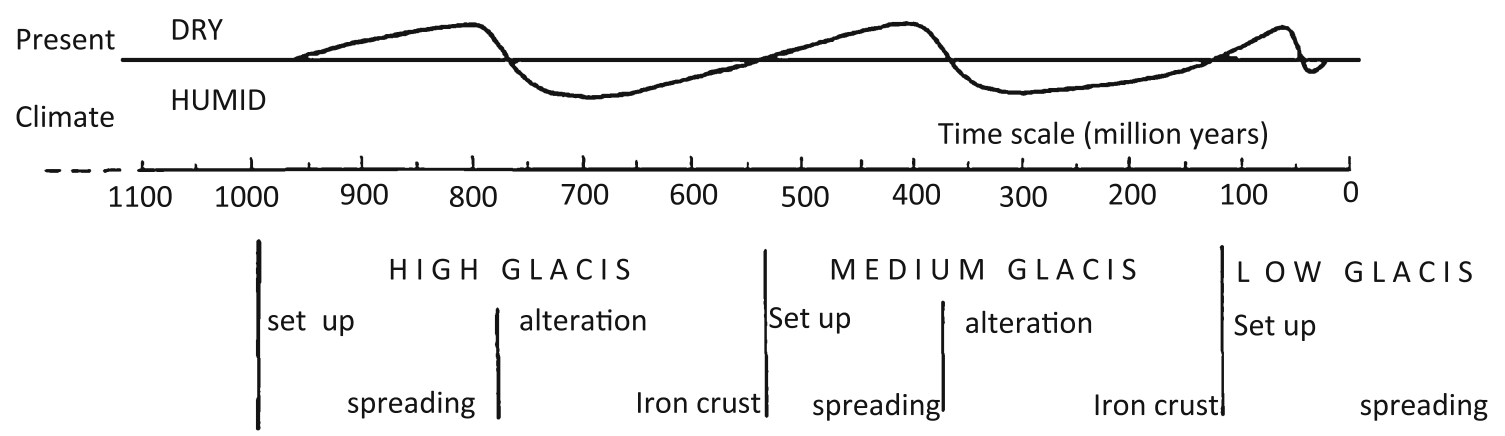

Figure 3. Morphoclimatic fluctuation in West Africa (Michel 1974).

For the system of 'staged glacis' (high glacis, medium glacis and low glacis), the chronology (figure 3) is closely modelled on the Quaternary fluctuation climatic phases (Avenard 1973). Michel (1969) notes that during the Quaternary period, west and central Africa experienced only two dry periods, or at the most three, before the beginning of the Würm glaciation and the wet periods are long. In the early and middle Quaternary, the climatic fluctuations are probably synchronous and of the same magnitudes throughout tropical Africa, north of the equator.

The beginning of the chronological evolution of the glacis system is marked by the fossilization of a very high glacis by the lavas of the 'mamelle' volcanism of Cap Vert (about 1 mya). The highglacis set-up begins after the 'mamelle' volcanic eruption, and ends about 780,000 years ago with the transition to the long wet period which continued up to 530,000 years ago. The medium-glacis set-up occurred at the expense of the former during a dry period lasting until about 380,000 years ago when the second wet period began and extended to 110,000 years ago. A new dry period, from 110,000 to 40,000 years ago, established the low glacis, and was then followed by a long pluvial period of 10,000 years which ended with the Inchirian transgression, dated from 35,000 to 31,000 years ago.

\subsubsection{Palaeosurfaces markers}

\subsubsection{Bauxite surface}

Well represented in Guinea and Ghana, the bauxite surface or 'African surface' is found in Ivory
Coast only in the state of isolated evidence like the Bongouanou Mountains (eastern boundary of the catchment). The bauxite crusts or aluminumiron crusts form plateaus so that no relief dominates. Their altitudes reach $600 \mathrm{~m}$ in the mountains of Bougouanou. This highlights the existence of a former levelling surface.

The discovery of large boulders of bauxite crusts with pisolitic features recemented on the hillside or in iron crust located at the foot of the hills at an altitude above $300 \mathrm{~m}$ (towards the catchment eastern boundary) reveals that these reliefs, which are presently devoid of crusts, contained bauxite crust (Bonvallot and Boulangé 1970).

\subsubsection{Intermediate landforms}

The intermediate landforms constitute a series of hills whose altitude ranges from 350 to $250 \mathrm{~m}$. These reliefs extend on both sides of the hills and are shaped to the detriment of the bauxite surface. The crusts of these reliefs, which redesign the dismantling products (stones, blocks of bauxite crust) of the bauxite surface, reflect an early surface of Mio-Pliocene period which is connected to bauxite plateaus (Avenard et al. 1971).

\subsubsection{High glacis}

The high glacis, unlike the Mio-Pliocene surface (intermediate landforms), is highly developed on the schists (figure 4). It forms vast iron-crusted plateaus, dated back to the early Quaternary, cut into parallel straps by the rivers on the left bank of 


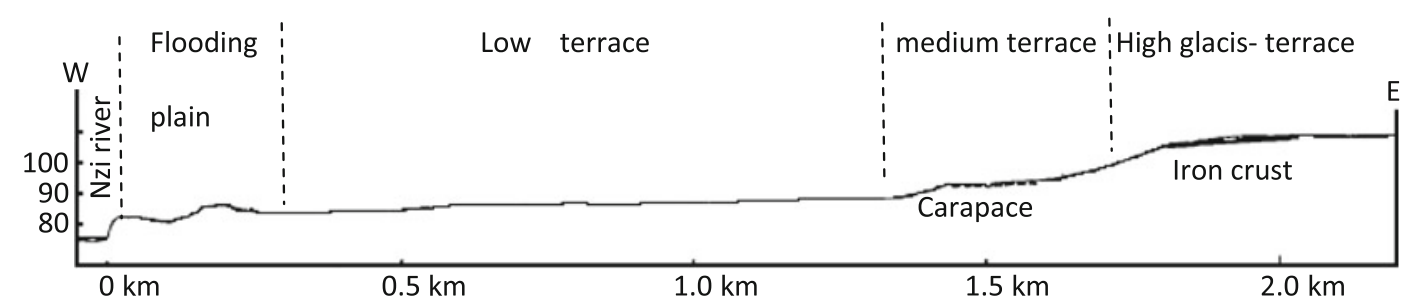

Figure 4. Cross-section of Nzi valley (left bank) downstream of the bridge of Dimbokro (Bonvallot and Boulangé 1970).

the Nzi River. In the granites of the right bank its surface is completely dismantled, subsisting only in the shape of surbased gravelly croups (Avenard et al. 1971).

The iron crust profile description by Yao et al. (1995) shows:

- at the bottom, a ferruginous and mottled clayey horizon;

- above the clayey horizon, a soil characterized by a greater abundance of coalescence and haematitic mottles, first soft and clayey, then harder towards the top of the profile, according to the neoformation of haematite;

- the upper part of the iron crust profile is marked by a very indurated crust where the alveoli or tubules of clay are in turn invaded by haematite.

The high glacis, which is very well developed, underwent erosion for a long period. Between the shaping of intermediate landforms and an erosive period of high-glacis set-up during the early Quaternary period, there is a long period of deep weathering (780,000 to 530,000 years ago) under humid and warm climate conditions (Avenard et al. 1971). These climatic conditions favour the preparation of weathering products for their subsequent mobilization. During the Mindel (480,000 to 430,000 years ago) interpluvial period, intermediate landforms were deeply eroded (Michel 1974).

\subsubsection{Medium glacis}

The medium glacis, a system of glacis which was little developed during the Quaternary period, is located immediately below the high glacis. Its extension is small, which postulates for a strong erosion of the Nzi River during a very aggressive episode after the deposit (Grandin 1976). The medium glacis is the latest levelling system that developed in the Dimbokro catchment (Avenard 1973).

The medium glacis is separated from the reliefs but is not conserved in the depressions. Nested in tens of metres of high glacis, it inherits its materials from the high glacis. It occupies a small area, but a good iron supply allowed the formation of a wellconserved crust (Grandin 1976).

\subsubsection{Low glacis}

After the set up of the medium glacis and its iron crust, the geomorphologic evolution of the catchment continued with the set up of a low glacis along valleys during the recent Quaternary period. There are few pebbles in the lower glacis, and when present, they are very blunt and often broken (Avenard et al. 1971).

\subsubsection{Distribution of palaeosurface markers in the granites and volcanosedimentary formations}

The synthesis of the work of Bonvallot and Boulangé (1970), Avenard et al. (1971), Grandin (1976) and Peltre (1977) in several regions of West Africa and particularly in the Dimbokro catchment allows an appreciation of the role played by the nature of the bedrock in the evolution of landforms. According to these authors, two factors are important for the resistance of iron crust for a given surface levelling.

- The aptitude of a rock (or an associated profile) for the iron crust process.

- The susceptibility to dismantling of an iron crust profile, which depends on the remains of the alterite underlying the iron crust.

Based on these two criteria, these authors show that

- The preservation of alterite is the dominant factor in the distribution of palaeosurface evidences according to the nature of the underlying rocks. The order of resistance of alterite ranges in a decreasing manner from compact kaolinitic alterite associated to greywacke deposit above metabasalt and schistose quartzite basements during geological set-up, to alterite of siliceous rocks, schists, and finally to the most fragile alterite in granitic regolith. In granitic regolith, the higher frequency of discontinuities (bedding, 
joints, fissuring), the granular texture, and the high porosity generally facilitate the withdrawal of fine materials in solution and allow the dislocation and the dissection of iron crust. Boulet (1972) showed for example that the quartz structure of granitic regolith made of coarse grain is the source of extreme leaching.

- In volcano-sedimentary terrain the glacis show a staged system (high glacis, medium glacis, and low glacis). In granites, this staged system does not exist. The undulating topography in granite terrain is due to the following assumptions: The iron crusts of high and medium glacis are both thinner and less compact, and thus can be easily fragmented. After the disappearance of the protective mantle, the early glacis is dissected by a network of small rivers.

- The erosion surface levelling is particularly wellpreserved in Birimian chains favourable to the iron crust process because of the abundance of rocks with mafic elements, and the iron crust determines the early topography. Traces of old surfaces are rare and analysis of the terrain is more difficult. In granites, the iron crust process is less widespread. In schist, the frequency of iron crust helps in understanding the morphoclimatic episodes.

\section{Geological investigations}

\subsection{Interpretation of geophysical data and lithologs}

At the Dimbokro catchment, the weathering profiles' characterization of the volcanosedimentary complex and granite formations required multiscale and multidisciplinary investigations. At site scale, geological investigations consisted in observing granites and volcanosedimentary bedrocks as well as the weathering profile on outcrops. Thereafter, we interpreted the lithologs (figure 5a) obtained from the cuttings collected every metre during the drilling phase. Our study is based on 102 lithologs from different boreholes. Interpretation of lithologs is supported by geophysical data (figure 5b) from the 1999 and 2000 geophysical campaign carried out by the Japanese Gift Project. This campaign was conducted across the Dimbokro catchment and consists in vertical electrical sounding (VES) at sites where wells are drilled. The Schlumberger method was used to conduct the electrical soundings with a maximum distance of $300 \mathrm{~m}$ between emission electrodes and an investigation depth of $150 \mathrm{~m}$. The combination of these data (lithologs, observations at

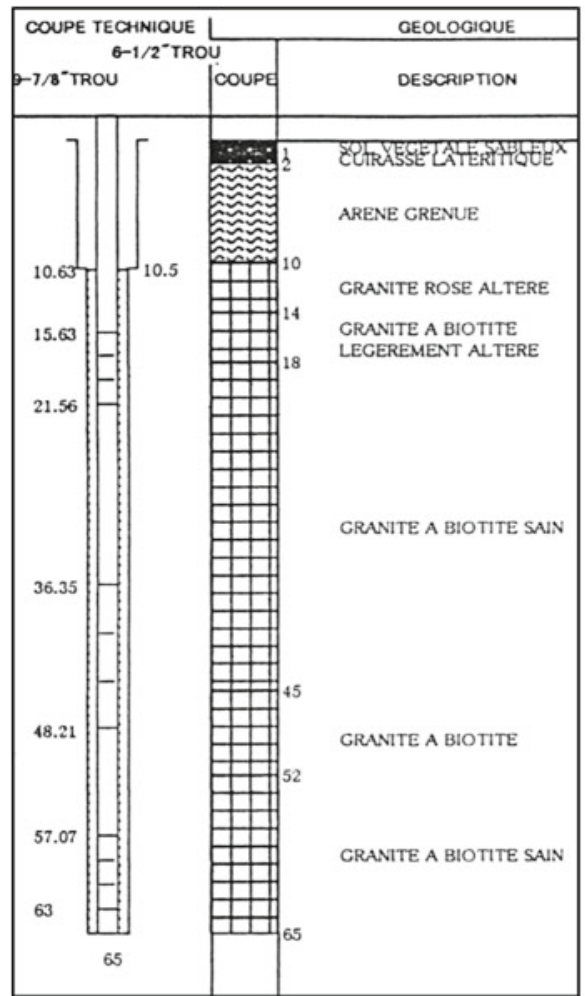

(a)

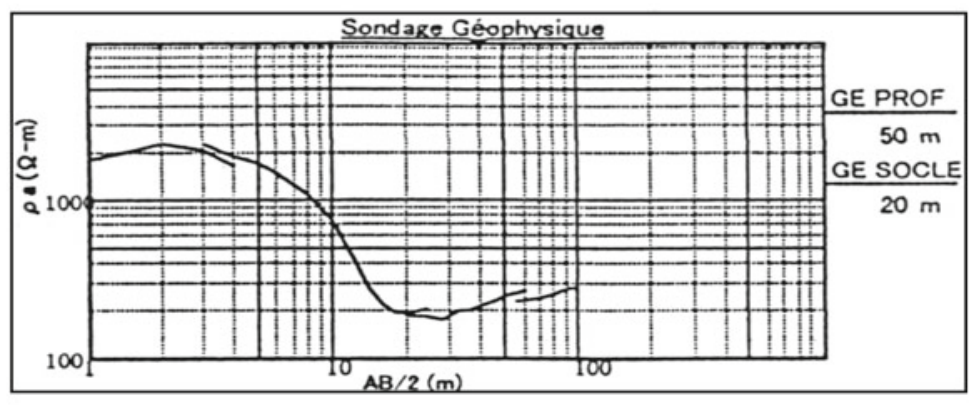

(b)

Figure 5. (a) Litholog realized in granites by drillers and (b) the associated VES. 

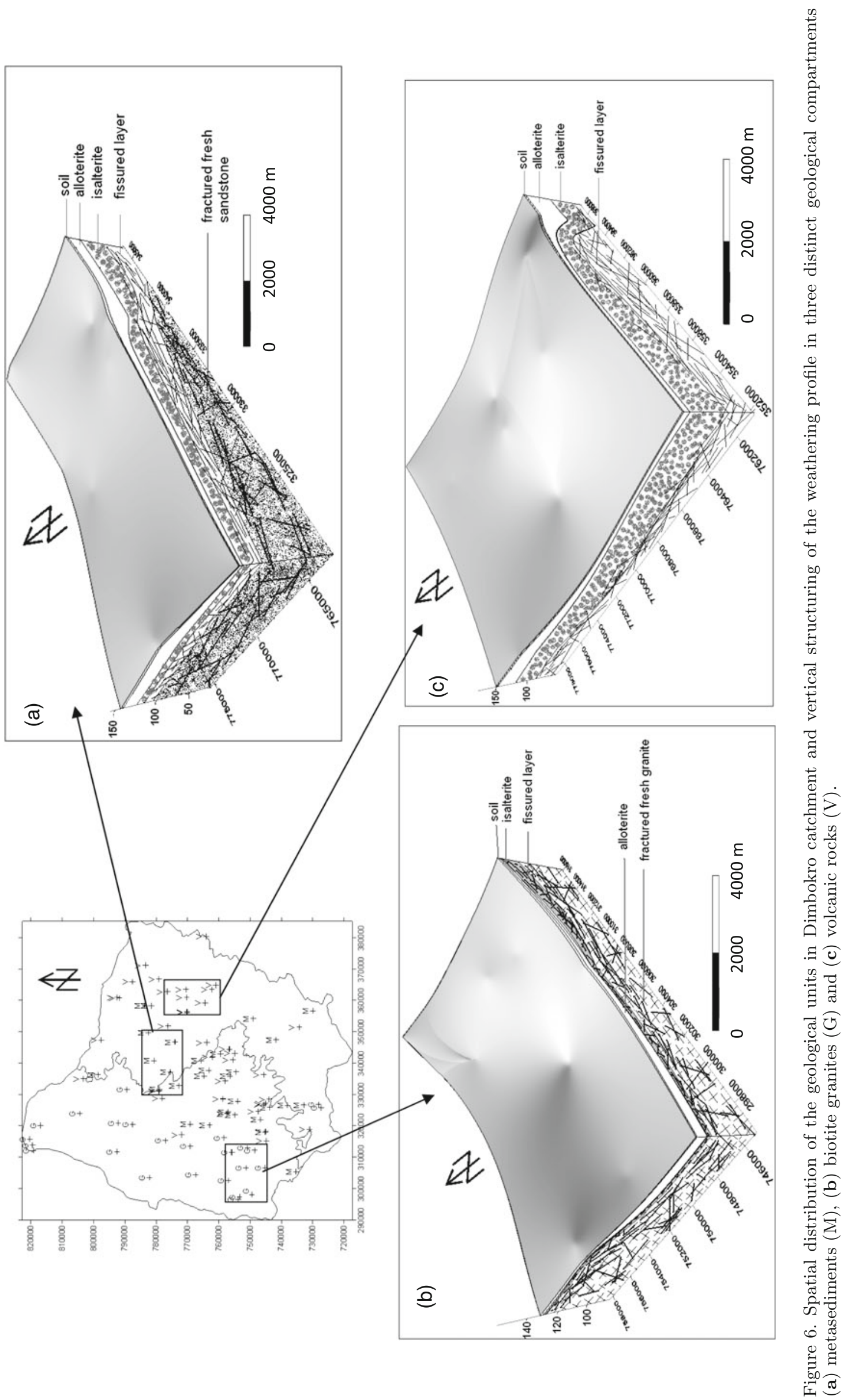
outcrop, VES) with the ground elevation of the top and bottom of each composite aquifer is used to build a block diagram showing the weathering profile associated to each rock type of the Dimbokro catchment.

\subsection{Field observations}

Outcrop observations show that the volcanosedimentary complex (commonly called the schist zone) is composed of volcanic and metasediment rocks where basements are of metabasalt and is schistose quartzite, respectively (cf. Geological setup). Their distribution is not well organized but distinct compartments of the geological units can be determined at the catchment scale (figure 6). They correspond to:

- metasedimentary compartments;

- a volcanic rocks compartment; and

- compartments made of a patchwork of metasedimentsary and volcanic rocks.

At outcrop, sometimes metabasalt experiences at the top a weathering process giving it an ochre colour and schistose aspect which make its identification difficult and favour confusion with schist. These formations outcrop often in the valleys of major rivers, such as the Orogo and the Nzi rivers, where several outcrops of metasediments (schistose quartzite) with schistosity planes oriented $\mathrm{N} 20^{\circ} \mathrm{E}$ were analysed. Northwards, volcanic rocks that outcrop in the bed of the Nzi River (upstream) exhibit different structures from those observed downstream (confluence OrogoNzi). These rocks are characterized by folded schistosity oriented $\mathrm{N} 10^{\circ}-30^{\circ} \mathrm{E}$ with $50^{\circ}$ to $60^{\circ} \mathrm{E}$ dip). Volcanic rocks are green due to the presence of amphibole, chlorite, sericite, and epidote colours involved in their composition (Peltre 1977). Granite rocks have a large extension in the western part of the Dimbokro catchment; they correspond to biotite granites and have a grainy structure. They outcrop in several sets of localities and show several fractures with variable length and aperture; apertures range from millimetres to centimetres with quartz fillings in some places. The most representative directions of fracturing are: $\mathrm{N}-\mathrm{S}\left(0^{\circ}-10^{\circ} \mathrm{E}\right.$ and $\left.\mathrm{N} 170^{\circ}-180^{\circ} \mathrm{E}\right) \mathrm{N} 40^{\circ}-50^{\circ} \mathrm{E}$, $\mathrm{N} 90^{\circ}-100^{\circ} \mathrm{E}, \quad \mathrm{N} 110^{\circ}-120^{\circ} \mathrm{E}, \quad \mathrm{N} 130^{\circ}-140^{\circ} \mathrm{E}$, and $\mathrm{N} 150^{\circ}-170^{\circ} \mathrm{E}$. The fracturing is characterized by subvertical dip with the fault plane illustrating sinistral movements.

For each of these rocks (granites, metasediments and volcanic rocks), five distinct layers that more or less follow the recent topography (figure 6) are observed.

\section{Vertical structuring of the weathering profiles in the different geological units}

\subsection{Weathering profile in granites}

The analysis of 32 lithologs shows that the granite weathering profiles follow a common scheme from the top to the bottom:

- soil,

- alloterite, a clayey layer;

- isalterite, a highly weathered layer with coarse granite debris;

- fissured layer, a slightly weathered layer of fissured granites, and

- fractured fresh granites.

The alloterite and isalterite layers together form the saprolite layer, also called the alterite or regolith layer. Although this scheme is classical, differences in layer thicknesses, which are sometimes important, are observed because of the topography and the contact zone between granites and volcanosedimentary formations (figure 7):

- The soil layer is derived from granitic regolith and is generally composed of a red, gravelly, and sandy soil. Its thickness varies from 0 to $2 \mathrm{~m}$ and can be up to $4 \mathrm{~m}$ in some places where the terrain is relatively flat.

This layer is particularly frequent and well preserved in some localities which are less affected by erosion. At slope break, it hardens sometimes in thin iron crust. The hillsides show another sandy-clayey coverage with occasional gravel materials.

- The alloterite layer has an average thickness that varies between 2 and $5 \mathrm{~m}$. It comprises white kaolinite that contains a few grains of sand but no trace of the original rock. In the valley zones the thickness of the alloterite layer can increase up to $20 \mathrm{~m}$ especially at the contact zones between granites and volcanosedimentary complex domains, which are very sensitive to weathering processes (Yao et al. 1995). At the western boundary of the granite domain, the alloterite layer is thin $(<1 \mathrm{~m})$ and tends to disappear towards the south-west boundary.

- The isalterite layer consists of highly weathered granites and its thickness varies between 3 and $5 \mathrm{~m}$. This layer is made of coarse debris at the bottom, and traces of the original rock are clearly visible in the cuttings except in the contact zone between granite and volcanosedimentary complex domains. In the western boundary of the catchment the thickness of this layer increases up to $10 \mathrm{~m}$ and tends to disappear towards the south-west and in the valley. 


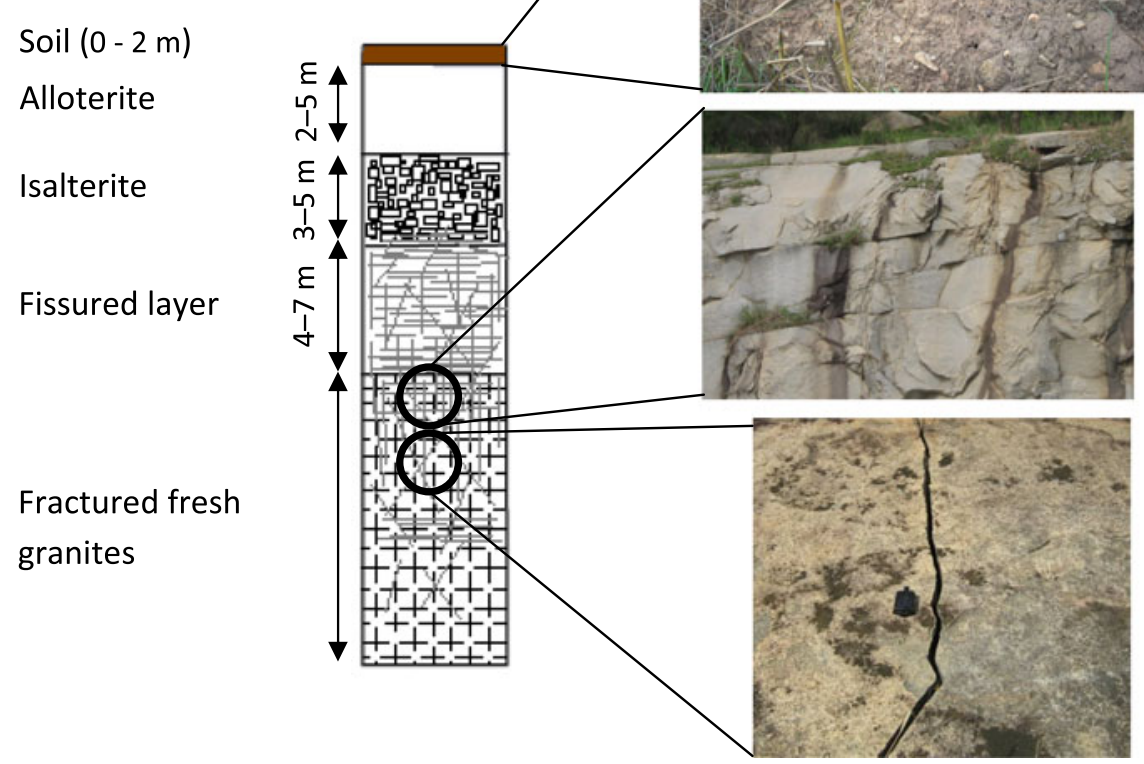

Figure 7. Vertical layering of the weathering profile in granites.

- The fissured layer comprises slightly weathered granites and its thickness varies between 4 and $7 \mathrm{~m}$. This layer is densely fissured and corresponds to the zone between the saprolite (alloterite and isalterite) layers and fractured fresh granites.

- Fractured fresh granites observed at outcrop have the form of large slabs of biotite granites. The top of fractured fresh granites is strongly fractured, with a predominance of horizontal joints. However, it comprises locally vertical to subvertical fractures, different in size and aperture, with fracture planes illustrating sinistral displacements. The decrease of the drill penetration velocity corresponds to the contact with fresh granites during the drilling phase. This information is used to confirm the data stemming from lithologs or to determine the fresh granites' depth in the absence of information on cuttings.

\subsection{Weathering profile in metasediments}

The analysis of 33 lithologs and observations at outcrop reveals that vertical layering of the weathering profile in metasediments comprises, from the top to the bottom, the following layers (figure 8):

- Soil layer. In its base, it reshuffles high quantities of quartz gravel coming from numerous quartz veins dismantled by material transit along hillsides. The soil layer thickness can reach $3 \mathrm{~m}$ and sometimes shows crusts with a significant concentration of iron oxide; it is generally welldeveloped in valley zones and in relatively flat grounds.

- Alloterite layer. This presents no trace of schistosity and is characterized by kaolinitization and oxidation of ferrous materials. Its thickness varies between 10 and $30 \mathrm{~m}$, and even more in depression zones. In some places the colour of clay ranges from yellow to orange and purple to green at the alloterite layer bottom.

- Isalterite layer. This comprises weathered schist and coarse materials in the form of arenaceous schists. This layer thickness ranges between 15 and $30 \mathrm{~m}$ and sometimes reaches $40 \mathrm{~m}$. This thickness changes as a function of the distance to the river; the smallest thicknesses are located close to the Nzi River bed and the biggest far away. The isalterite layer has a greenish colour due to the presence of chlorite. In the isalterite layer, schistosity planes are conserved regardless of the degree of maturity (figure 8). They have subvertical dip and are oriented $\mathrm{N} 40^{\circ}-50^{\circ} \mathrm{E}$.

- Fissured layer. This consists of slightly weathered schistose quartzite. The limit between fissured and saprolite layers (schistose alloterite and isalterite) can be appreciated by the degree of weathering. Contrary to saprolites, fissured layers are slightly weathered and show traces of fresh basement. The limit between saprolite and fissured layers is also highlighted by a 


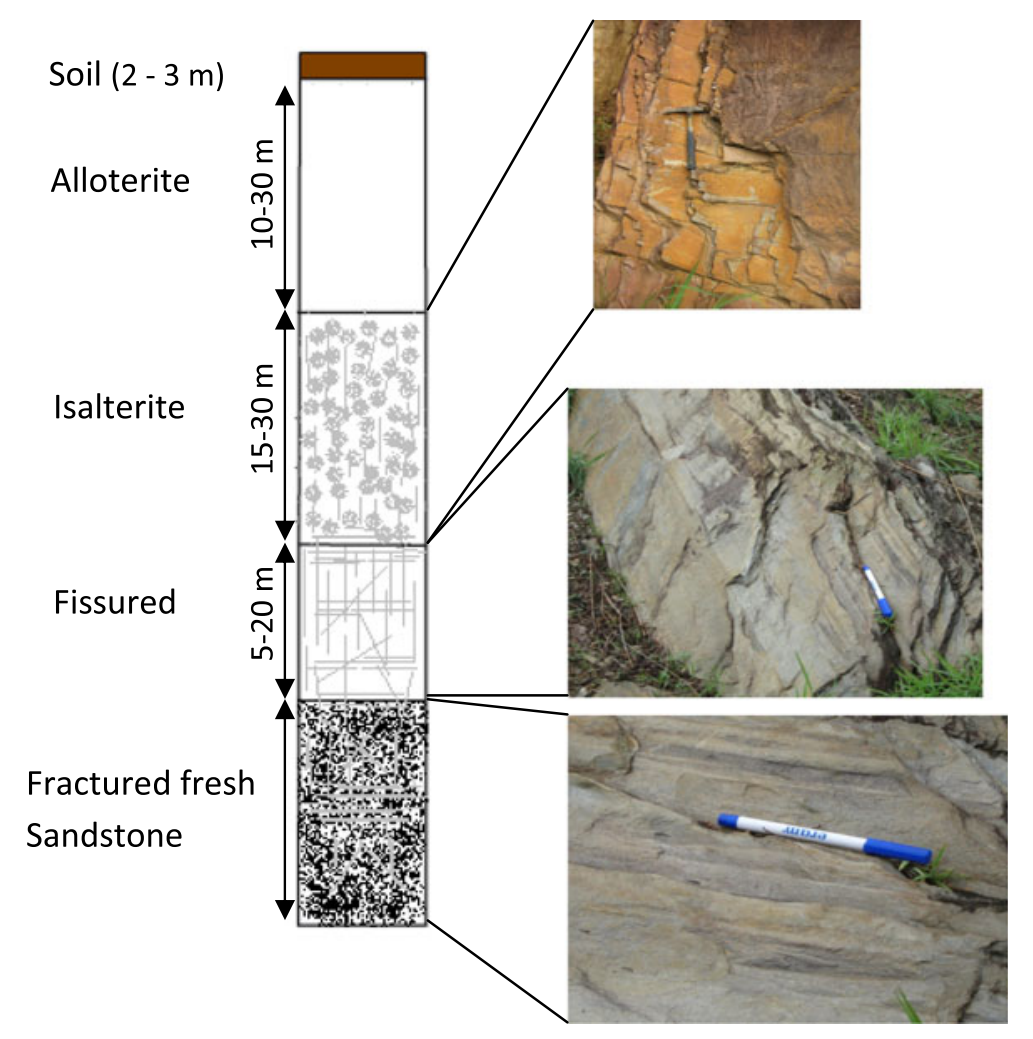

Figure 8. Vertical layering of the weathering in metasediments.

marked variation in electrical resistivity values in Schlumberger VES. The fissured layer thickness varies between $5 \mathrm{~m}$ (where fresh schistose quartzite outcrops in the Nzi River bed) and $20 \mathrm{~m}$ in flat topography zones. In some places close to the Nzi River bed, the lower limit of the fissured layer is not reached during drilling.

- Fractured fresh schistose quartzite layer. This constitutes the basement of metasediments and rarely outcrops. This basement is fractured and consists of quartz grains. Fractured fresh basement shows some isolated water arrivals during the drillings.

\subsection{Weathering profile in volcanic rocks}

Volcanic rocks are commonly grouped under the term 'green rock'. This term covers a wide sense and indicates metabasalt, meta-andesite, metadolerite, or metagabbro (Peltre 1977). In the Dimbokro catchment, the volcanic rocks basement is made of folded and weakly metamorphosed basalts overlaid by schistose formation set-up during the main deposit phase (cf. geological set-up).

The analysis of 37 lithologs and observations at outcrop reveals that vertical layering of the weathering profile in volcanic rocks is made up of:

- soil layer;

- alloterite layer, a clayey schistose layer;
- isalterite layer, a schistose layer with conglomerate features;

- fissured layer, and

- fractured fresh metabasalt (figure 9).

From the top to the bottom the layers observed along the weathering profile are:

- Soil layer. Its thickness varies from 2 to $4 \mathrm{~m}$ and it is observed at the top of the profile in most cases. Soil is well preserved in the plateau zone due to its well-developed iron crust (related to the successive erosion phases from Mio-Pliocene to the recent Quaternary period) and is protected against dismantling. On hillsides it is generally removed, exposing stony materials.

- Alloterite layer. Its thickness varies between 20 and $45 \mathrm{~m}$ and it contains a succession of yellow, orange-yellow, and even purple clay in some places. No trace of original material is visible in alloterite layers. In alloterite, no water arrival is recorded during drillings.

- Isalterite layer. This comprises weathered schist. It is greenish, contains grains of quartz, and shows a conglomerate aspect. It presents subvertical schistosity oriented $\mathrm{N} 40^{\circ}-50^{\circ} \mathrm{E}$. Its thickness varies from 20 to $35 \mathrm{~m}$ and is highly variable depending on the topography. It decreases westward towards the Nzi River bed and increases towards the eastern boundary of the Dimbokro 


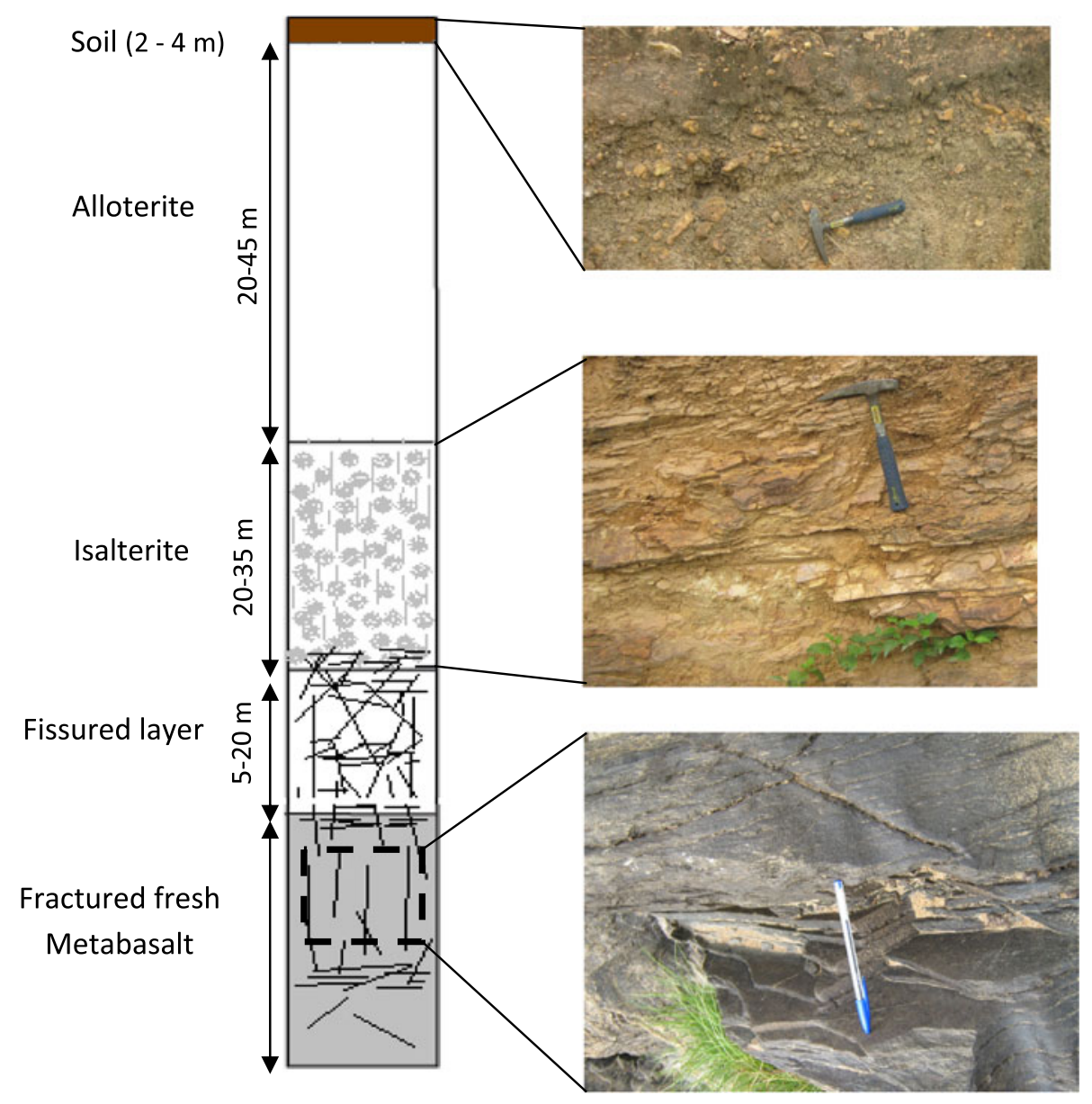

Figure 9. Vertical layering of the weathering in volcanic rocks.

catchment. In some isolated cases, boreholes close to the Nzi River bed show significant thicknesses of isalterite (about $40 \mathrm{~m}$ ), which might suggest the existence of faults which may favour the weathering process (Yao et al. 1995).

- Fissured layer. This is made of slightly weathered schist that contains a high frequency of oxidized quartz veins intrusion and has a green to grey colour. Fissured layers have an average thickness that range between 5 and $20 \mathrm{~m}$, but they are relatively thin in the vicinity of the Nzi River, with an average thickness of around $10 \mathrm{~m}$. They become thicker towards the eastern boundary of the catchment, where they reach $40 \mathrm{~m}$. Most boreholes drilled near this boundary did not reach the bottom of this layer. This explains why the lower limit of this layer is not represented in the metasediments block diagram at the eastern boundary. When the thickness of the fissured layer is high, the thicknesses of isalterite and alloterite above the fissured layer are low, and vice versa except in the localities close to the Nzi River.

- Fractured fresh metabasalt outcrops in a few places in the Nzi River bed and is generally grey to black colour. This layer comprises folds whose axes are typically oriented $\mathrm{N} 100^{\circ}-110^{\circ} \mathrm{E}$ with $60^{\circ} \mathrm{E}$ dip. Several subvertical fractures of $\mathrm{N} 20^{\circ}-30^{\circ} \mathrm{E}$ direction are observed on bedrock at outcroppings.

\section{Discussion}

5.1 Geometry and structure of weathering profile in granites, metasediments, and volcanic rocks. Similarities and differences between these different profiles

Granites, metasediments, and volcanic rocks in Dimbokro catchment experience both the same weathering and the same erosion cycles during the palaeoclimatic fluctuations from Eocene to the recent Quaternary period. Comparing the structure of the weathering profile of the rock type will be an important tool to interpret the hydrodynamic behaviour of each profile type.

In Dimbokro catchment, the total thickness of the granites' weathering profile $(2-20 \mathrm{~m})$ is lower than the thickness of the metasediments' weathering profile $(30-80 \mathrm{~m})$, which is lower than the 
thickness of the volcanic rocks' weathering profile $(40-100 \mathrm{~m})$. In the metasediments and the volcanic rocks, the weathering profile above the fresh basement presents the same vertical schistosity of direction $\mathrm{N} 40^{\circ}-50^{\circ} \mathrm{E}$. The difference in profile thickness of the three different rocks in Dimbokro catchment is linked to (i) the susceptibility of the rock type (or associated weathering profile) to the iron crust process and (ii) the susceptibility of the iron crust to dismantling, which depends on the resistance of the alterite underlying the iron crust. Indeed, many studies (Avenard et al. 1971; Grandin 1976; Peltre 1977) done in the Dimbokro catchment reveal that granite rock is less prone to the iron crust process than schist, which is itself less prone than the basalt (the basement of volcanic rocks). The alterite from metasediments and volcanic rocks is more resistant to dismantling than alterite from granites. These different considerations explain why the thickness of the granite profile is smaller than that of volcanosedimentary rocks. The difference in thickness between metasediments and volcanic rocks is linked to the fact that iron crust is better developed in volcanic rocks than in metasediments. In the volcanic rocks domain, the resistance of the profile to dismantling is illustrated by the presence of different types of iron crust levels, which are evidence of palaeosurfaces set-up from Mio-Pliocene to recent Quaternary. Finally, the mafic nature of the volcanic rocks basement also plays a role in the iron crust process due to its abundance in ferromagnesian elements.

For each rock type, the weathering profile shows the same vertical structure with four separate layers below the soil layer. The top and the bottom follow the recent topography (cf. figure 6) but the thickness of each layer is not constant in the catchment. The comparison of each layer of the weathering profiles associated to each of the three geological formations of Dimbokro catchment (figure 10) shows that:

1) Alloterite thickness in granites is lower than in metasediments which itself is lower than in volcanic rocks. In granites this layer is of sandy clay type while it is of colloidal nature in metasediments and volcanic rocks.

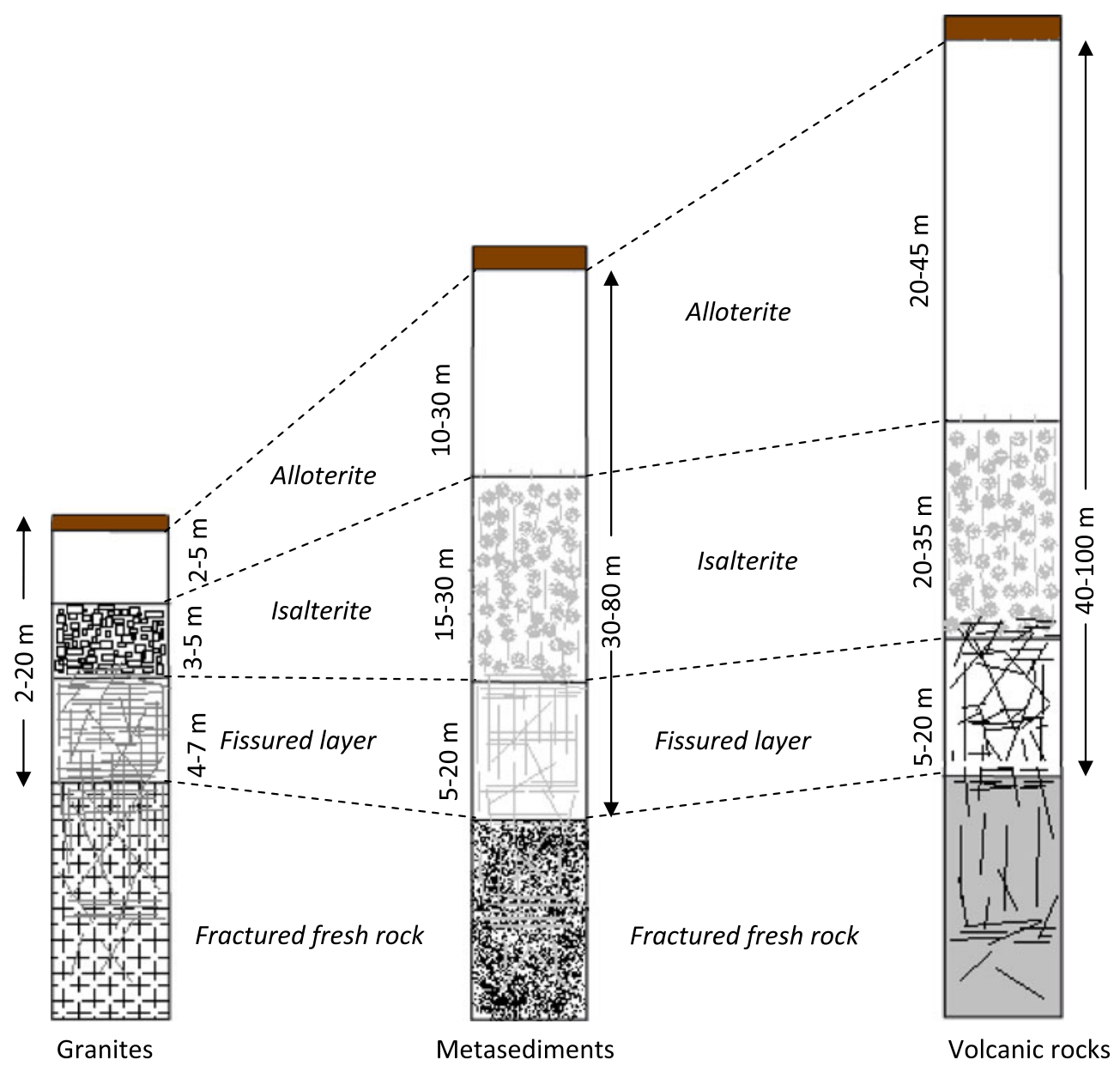

Figure 10. Comparative scheme of weathering profile model of the three rock types. 
The alloterite layer is responsible for the difference in thickness between the total weathering profiles of the two schistose formations (metasediments and volcanic rocks). Indeed, the large thickness of the alloterite layer is related to the fact that the alloterite layer is generally overlaid by iron crust coverage which protects it against dismantling.

2) In granites, as in metasediments, the isalterite layer thickness is almost similar to the alloterite layer thickness, whereas the isalterite layer thickness is smaller than the alloterite layer thickness in volcanic rocks. In granites, the isalterite thickness is lower than in metasediments, whereas it is similar in both metasediments and volcanic rocks.

In metasediments and volcanic rocks, the isalterite layer is characterized by well-preserved identical schistosity oriented $\mathrm{N} 40^{\circ}-50^{\circ} \mathrm{E}$ with subvertical dip. In granites the bottom of the isalterite, which is clearly visible, corresponds to a coarse material layer, while the bottom of the isalterite layer in metasediments and volcanic rocks is characterized by fissuring, which constitutes the transition zone between the isalterite layer and the underlying fissured layer.

3) The fissured layer in metasediments is thicker than the fissured layer in granites but is as thick as the fissured layer in volcanic rocks.

In granites, thicknesses of the fissured layers, alloterite layer, and isalterite layer are almost similar. On the contrary, in metasediments and volcanic rocks, the fissured layer's thickness is smaller than the alloterite and isalterite layers' thicknesses, but the fissured layer's thickness in metasediments is similar to the fissured layer's thickness in volcanic rocks.

In granites, as in metasediments and volcanic rocks, the fissured layer is characterized by a dense fissuring with horizontal predominance.

In block diagrams, the fissured layer thickness evolves with the alloterite and isalterite layers' thicknesses according to two distinct schemes:

(i) from west to east, the thickness of the fissured layer in granites and volcanic rocks increases inversely proportional to the thickness of alloterite and isalterite layers; (ii) from north to south, the fissured layer's thickness does not present any changes for the three geological formations.

4) In the granites, the depth of the fractured fresh basement is lower than in metasediments and volcanic rocks. Fractured fresh basement is characterized by a dense fracturing, mainly horizontal, whose genesis can be attributed to remobilization of granite rocks and magma cooling during successive tectono-volcanisms from the 'Liberian' to the 'Birimian' phases. In metasediments the depth of the fractured fresh basement is higher than in granites but lower than in volcanic rocks.

In metasediments and volcanic rocks, the fractured fresh basement comprises a predominance of vertical fractures. These vertical fractures are intersected by horizontal fracturing caused by quartz veins intrusion set up during successive tectono-volcanisms in Dimbokro catchment.

\section{Conclusion}

The weathering profile characterization in granites, metasediments, and volcanic rocks in Dimbokro catchment reveals that each of the three profiles comprises four separate layers overlaid by a soil layer (alloterite, isalterite, fissured layers, and fractured fresh basement), which are more or less parallel to the recent topography.

In granites, the weathering profile is relatively thin due to the absence of iron crust, which protects weathering products against dismantling.

In metasediments, iron crusts develop better than in granites; in these rocks the alterite (alloterite and isalterite) is of kaolinitic type (linked to greywacke deposit above metasediment basement during geological set-up) and is thus more resistant to dismantling. Consequently, metasediments exhibit thicker profiles than granites.

In volcanic rocks, the weathering profiles are generally complete and have the largest thickness, which again is related to a well-developed iron crust that protects the rocks from dismantling. The high reliefs associated with the rocks show that they have been subjected to less dismantling than metasediments and granites.

In each profile, the fissured layer is dominated by horizontal fissures (discontinuities in the alteration zone). But the structures of the fresh basement are different:

- In granites, the fractured fresh basement comprises a predominance of horizontal fractures (discontinuities in the fresh basement).

- In metasediments and volcanic rocks the fractured fresh basement is characterized by vertical fractures intersected by horizontal discontinuity due to quartz veins intrusions.

Regarding the thicknesses it is noted that:

- In granites, alloterite, isalterite, and fissured layers have similar thicknesses;

- In metasediments, the thickness of the fissured layer is lower than those of the alloterite and isalterite layers, which both have similar thicknesses; 
- In volcanic rocks, the thickness of the fissured layer is also lower than those of the alloterite and isalterite layers.

In addition to the geometry and the structural characterization of different layers of weathering profile in Dimbokro catchment, a study incorporating data of the regional faults (due to different tectonic phases) and the hydraulic properties of each layer of the weathering profile must be considered to appreciate the incidence of the weathering profile structure on hydrodynamic behaviour of Dimbokro catchment aquifer.

\section{Acknowledgements}

The authors wish to express their sincere thanks to the Islamic Development Bank for supporting the PhD studies of Mahamadou Koita during which this research was carried out. The authors greatly appreciate the help of Mr Kapo Martin Coulibaly for rereading and all other persons who provided assistance during field campaigns.

\section{References}

Avenard J M 1973 Evolution géomorphologique au quaternaire dans le centre ouest de la Côte d'Ivoire; Revue de Géomorphologie Dynamique 22 145-160.

Avenard J M, Eldin M, Girard G, Sirconlou J, Touchebeuf L P, Guillaumet J L, Adjanohoun E and Perraud A 1971 Le milieu naturel de la Côte d'Ivoire; Mémoire ORSTOM 50 11-72.

Blot A 1980 L'altération climatique des massifs de granites du Sénégal; Travaux et Documents de l'ORSTOM, 29p.

Bonvallot J and Boulangé B 1970 Note sur le relief et son évolution dans la région de Bongouanou (Côte d'Ivoire); Cahier ORSTOM série Géologie 2 171-183.

Boulet R 1972 Modalités d'action du lessivage dans les sols tropicaux développés sur granites (Haute-volta): étude micromorphologique; Cahier ORSTOM Série Pédologie $10321-341$.
Dewandel B, Lachassagne P, Wyns R, Maréchal J C and Krishnamurthy N S 2006 A generalized 3-D geological and hydrogeological conceptual model of granites aquifers conrolled by single or multiphase weathering; J. Hydrol. $330260-284$.

Freyssinet P and Farah A S 2000 Geochemical mass balance and weathering rates of ultramafic schists in Amazonia; Chem. Geol. 170 133-151.

Geirnaert W, Groen M, Van Der Sommen J and Leusink A 1984 Isotope studies as a final stage in groundwater investigations on the African shield, challenges in African hydrology and water resources; Proceedings of the Harare Symposium; IAHS Publ. 144 141-153.

Grandin G 1976 Aplanissement cuirassés et enrichissement des gisements de manganèse dans quelques régions d'Afrique de l'ouest; Mémoire ORSTOM, 82p.

Grandin G and Delvigne J 1969 Les cuirasses de la région birrimienne volcano-sédimentaire de Toumodi, jalons de l'histoire géomorphologique de la Côte d'Ivoire; C.R. Acad. Sci. Paris 269 1474-1477.

Maillary J C 1965 Notice explicative des cartes hydrogéologiques d'Abengourou et Dimbokro (1/200 000), 34p.

Michel P 1969 Chronologie du quaternaire des bassins des fleuves Sénégal et Gambie. Essai de synthèse; Bull. de l'Ass. Fr. pour l'étude du quaternaire 2 30-51.

Michel P 1974 Les glacis cuirassés d'Afrique occidentale et centrale; Colloques scientifiques de l'Univ. De tours, pp. 70-79.

Nahon D B 1986 Evolution of iron crusts in tropical landscapes; In: Rates of chemical weathering of rocks and minerals (eds) Colman S M and Dethier D P; Academic Press Orlando Florida, pp. 169-191.

Peltre P 1977 Le «V» baoulé: Héritage géomorphologique et paléoclimatique dans le tracé du contact forêt-savane; Cahier ORSTOM, 190p.

Tagini B 1971 Esquise structural de la Côte d'Ivoire. Essai de géotechnique régionale; SODEMI, Abidjan.

Taylor R and Howard K 2000 A tectono-geomorphic model of the hydrogeology of deeply weathered crystalline rock: Evidence from Uganda; Hydrogeol. J. 8 279-294.

Wright E P 1992 The hydrogeology of crystalline basement aquifers in Africa; Geol. Soc. London, Spec. Publ. 66 1-27. doi: 10.1144/GSL.SP.1992.066.01.01.

Yao D, Delor C, Gadou G, Kohou P, Okou A, Konaté S and Diaby I 1990 Notice explicative de la carte géologique feuille de M'Bahiakro; Mémoire SODEMI, Abidjan (Côte d'Ivoire).

Yao D, Delor C, Gadou G, Kohou P, Okou A, Konaté S and Diaby I 1995 Notice explicative de la carte géologique feuille de Dimbokro; Mémoire SODEMI, Abidjan (Côte d'Ivoire). 